\title{
A Contrastive and Comparative Study of Ellipsis in Persian and English
}

\author{
Farsça ve İngilizce'deki Ellipsisin Çelişkili ve Kıyaslamalı Çalışması
}

\begin{abstract}
Mohammad RAHI*
Abstract: This study attempts to analyze English and Persian research articles in respect to the occurrence of ellipsis as a type of cohesive tie. To this end 20 research articles (10 articles in each language) were analyzed in terms of their elliptical categories. For this purpose, Kavousi Nejad's early and late taxonomies (1997, 1998) and Quirk et alii, (1985) classification of ellipsis were employed. Another significant objective of this study was to predict the errors Iranian EFL learners are likely to make when they employ English ellipsis in their written and spoken work. The most important find from the present study was that these three models of classification are applicable to Persian and English ellipsis. The other important find was that Persian and English have the same types of ellipsis, the only difference being that one of the types of ellipsis, namely the quasi-ellipsis, is present in English but is absent from Persian. This verifies McCarty's claim (2005) that ellipsis is probably a universal feature of languages. The final find of this study is that the grammatical options which realize ellipsis in Persian discourse vary markedly from those realized ellipsis in English. It is this variation in the realization of ellipsis which leads to certain errors on the part of Iranian EFL learners.
\end{abstract}

Keywords: Contrastive, comparative, ellipsis, errors, discourse

Özet: $\mathrm{Bu}$ çalışma, elipsisin uyum sağlayıcı bir bağ tipi niteliğinde bulunmasıyla ilgili olarak İngilizce ve Farsça araştırma makalelerini analiz etmeye yönelik bir çabaydı. Bu amaçla çalışmada eliptik kategoriler baz alınarak (her bir dilde on adet olmak üzere) 20 araştırma makalesi analiz edildi. Kavousi Nejad'ın erken ve geç taksonomileri (1997, 1998) ve Quirk ve diğerlerinin (1985) elipsis sınıflandırması kullanıldı. Çalışmanın bir diğer hedefi İngilizce eğitimi alan İranlıların yazılı ve sözlü performasyonlarında elipsisi kullanırken yapmaları ihtimal dahilinde olan hataları öngörmekti. Çalışmanın en önemli bulgusu bu üç sınıflandırma modelinin Farsça ve İngilizce'ye uygulanabilirliğiydi. Diğer önemli keşif Farsça ve İngilizce'nin aynı elipsis tiplerine sahip olduğu, tek farkın İngilizce'de mevcut olan bir elipsis tipinin, diğer bir ifadeyle yarı-elipsisin Farsça'da bulunmayışıydı. Bu durum McCarty'nin (2005) elipsisin büyük ihtimalle dillerin üniversal bir özelliği olduğu yönündeki iddiasını doğrulamaktadır. Çalışmada elde edilen son bulgu Farsça ifadede elipsisi gerçekleştiren gramatik opsiyonların İngilizce'de elipsisi gerçekleştirenlerden kayda değer oranda farklı olduğudur. İngilizce öğrenen İranlıları belirli birtakım hatalar yapmaya yönelten de elipsisin gerçekleştirilmesindeki bu varyasyondur.

Anahtar Kelimeler: Çelişen, kıyaslamalı, elipsis, hatalar, söylem

During the early seventies a large number of studies investigating the issue of cohesion were flourished. The most prominent study was carried out by Halliday and Hasan (1976) which looked at the English cohesive devices that linked sentences to each other. Cohesion which is the factor weaving a text together is believed to play an important role in the writing quality of learners (Larson, 1984). Cohesion which is classically divided by Halliday and Hasan (1976) into grammatical cohesion and lexical cohesion is a less embedding concept which can result in

\footnotetext{
* Islamic Azad University, Tehran, Iran, s.khezrlou@gmail.com
} 
the overall coherence of a written text. The study of both cohesion and coherence is a favorite research field amongst linguists. Both concepts, traditionally connected with the process of reading, have become an important tool in teaching learners how to write a text. $E F L$ classes should help students to understand the use of cohesive linkers in texts and heed any logical pattern which could help them to organize the text in a way that can be understood by the reader (Palmer, 1999). According to Halliday and Hasan (1976), Halliday (1985), and Hasan (1984), the cohesiveness of a text greatly depends upon the appropriate use of cohesive devices. These devices were classified by Halliday and Hasan as reference, ellipsis, substitution, conjunction, and lexical cohesion.

According to Richards and Schmit $(1992,86)$, the concept of cohesion refers to "the grammatical and/or lexical relationship between the different elements of the text". Halliday and Hasan (1976), too, argue that cohesion is identified partly through grammar and partly through vocabulary:

It is necessary to consider that cohesion is a semantic relation but, like all the components of semantic system, it is realized through the lexicogrammatical system. The lexicogrammatical system includes both grammar and vocabulary. Of the cohesive types, reference, substitution, and ellipsis are grammatical; lexical cohesion is lexical; and finally conjunction is on the borderline of the two, mainly grammatical, but with a lexical component in it (Halliday, \& Hasan, 1976, 5).

Bearing this definition in mind, the following cohesive devices can be enumerated:

Reference: reference refers to the semantic relationship between words and the things that they stand for. This term in semantics conveys the relationship between words and that to which they are associated with in the real world. In Halliday and Hasan's model (1976) this meaning is provided in a restricted way; reference is limited to the relationship of identity which holds between two linguistic expressions.

Conjunction: words that join together word, phrases and sentences. This cohesive device involves the use of formal markers to relate sentences, clauses and paragraphs to each other. This tie is important because it shows the writer's directions concerning pieces of information which are provided and it is of four kinds namely, additive, adversative, casual and temporal (Baker, 1992).

Substitution: as defined by Bloor and Bloor $(1995,96)$, substitution is used where the speaker or writer wishes to avoid repetition of a lexical item and is able to draw on one of the grammatical resources of the language to replace the item. Baker $(1992,186)$ defines this tie as being a grammatical relation in which, an item (items) is replaced by another item (or items).

Ellipsis: is by nature like substitution by nothing as defined by Halliday and Hassan (1976). Baker (1992) defines it as the process in which an item is omitted.

Lexical Cohesion: Bloor and Bloor $(1995,100)$ argue that, lexical cohesion refers to the cohesive effect of the use of a lexical item in discourse where the choice of an item relates to the choices that have gone before. Baker $(1992,202)$ defines this tie from another angle: lexical cohesion refers the role played by the selection of vocabulary in organizing relation within a text. Lexical cohesion has two aspects, reiteration and collocation.

Although all the above mentioned categories of cohesion are understood to play an important role in the cohesion of a text, the present study only analyzed the ellipsis category in Persian and English writing, to see if the differences and similarities between the two languages would be facilitative or debilitative. 


\section{Ellipsis in Persian}

As in English, ellipsis occurs in Persian and several scholars have examined the issue. There have been different arguments, however, concerning the location of ellipsis in Persian sentences. Miremadi (1998), for instance, notes that ellipsis is not only a feature of contemporary Persian, but also a feature of earlier stages of this language, that is why one may come across a great many examples of ellipsis in classical prose and Persian verse texts. These examples of ellipsis can be grouped into three main categories:

a) Lexical ellipsis

b) Semantic or meaning based ellipsis

c) Verbal ellipsis.

There have been numerous arguments regarding the type of ellipsis in Persian texts (e.g., omission of the verb of the second clause of the sentence (Vahidian, 1969); omission of the conditional particle (Khayyampour, 2002); omission of prepositions (Farshidvard, 1969). It is well known that Persian, in contrast to English, is a pro-drop language which has finite nullsubject declarative sentences (Cook, \& Newson, 1988). Thus, different elements of language with regard to the linguistic and pragmatic context can be omitted. Mashkour (1994) is perhaps, the first linguist who implicitly refers to linguistic context as one of the factors which could be used to explain the cohesive tie of ellipsis and identifies the speaker's intention to avoid mentioning the accomplishment of an action as one of the reasons for the omission of the subject of a sentence. It seems that the consideration of the role of linguistic and pragmatic factors in the application of ellipsis assumes a much greater role than had previously been considered. Mashkour assumes that the avoidance of lengthy sentences and the observation of the principle of economy are the main reasons for ellipsis.

Regarding the undeniable significance of cohesive devices in any language and their impact upon the learning of languages, the present study was carried out to identify the similarities between the English language and the Persian language in respect to ellipsis and took a useful step in predicting and in preventing the ellipsis related errors made by Iranian EFL learners.

The present study aimed at finding answers to the following questions:

1) Do the Persian and the English languages have the same types of ellipsis?

2) Do the Persian and the English languages have the same number of ellipsis?

3) Do the differences between the Persian and English ellipsis resulted in EFL learners' errors?

4) Do the similarities between Persian and English ellipsis facilitate the learning and use of this grammatical link in the writing and speech of Iranian EFL learners?

\section{Method}

\subsection{Sources of Data}

The data for this study consisted of twenty English and Persian research articles, i.e., ten articles from each language. Ten articles from Quarterly journals of Foreign Language Research were selected to provide the required data source for the Persian texts in the present study. The English Language Learning Journal was selected as the database for the analyses of English ellipsis. In order to make the analysis manageable, articles in the field of language learning in each language were selected. To have an almost equal amount of data in English and Persian, the first 250 words of each text were analyzed.

\subsection{Procedures of Data Analysis}

To analyze the data, first every sentence in each text and the type of ellipsis was detected. 
Comparisons of similarities and differences between the two languages in terms of ellipsis were made according to the first 250 words of each selected article.

Three elliptical frameworks were selected upon which the data analysis was based. For the analysis of ellipsis in both the Persian and English languages, Kavousi Nejad's early and late taxonomies $(1997,1998)$ and Quirk et. alii. (1985) classification of ellipsis were employed.

Kavousi Nejad (1997) included nominal ellipsis, verbal ellipsis, and clausal ellipsis as the three main categories of ellipses. In the 1998 model, however, Kavousi Nejad had the following categories:

Similar to the cohesive device of reference, ellipsis can be divided into anaphoric and cataphoric ellipsis.

Anaphoric ellipsis: in this type of ellipsis, the missing element can be retrieved verbatim by looking back in the text.

Cataphoric ellipsis: in this sort of ellipsis the missing element can be retrieved from the text by looking forward in the text.

Quirk et. alii. (1985) classification of ellipsis included the following:

Strict ellipsis: in this kind of ellipsis the exact word is retrievable verbatim from the surrounding context.

Standard ellipsis: in this kind of ellipsis, the missing element is not morphologically speaking exactly the same as the antecedent.

Quasi-ellipsis: in this kind of ellipsis, the complete form of the second clause is not retrievable, unless some changes take place.

Situational ellipsis: in this kind of ellipsis, the missing element can be identified by referring 'outward' from texts rather than being retrievable from the surrounding text.

Structural ellipsis: in this type of ellipsis, structure plays a significant role in identifying the missing element.

Semantic ellipsis: in this type, the ellipted words are not precisely recoverable from the previous text.

\section{Results}

Based on the comparative and contrastive analysis of Persian and English ellipsis carried out in the study, the following significant results have been obtained.

With regard to the first two questions, the following results were obtained:

a) Persian and English have the same types of ellipsis except for one type namely quasiellipsis which exists in English but is not found in Persian.

b) Persian has one type of ellipsis less than English.

To answer the third and fourth questions, the Persian and English ellipsis were compared and contrasted and the following results were obtained:

a) There are a number of significant similarities between English and Persian as far as ellipsis is concerned.

b) There are also a number of significant differences between the two languages involved.

c) Certain kinds of similarities result in the easier learning of English ellipsis by Iranian $E F L$ learners and fewer errors when using elliptical structures. This is in line with the strong version of contrastive analysis which assumes that the more similar L1 and L2 systems are, the easier would be the learning of L2, and the fewer errors they would commit (Keshavarz, 1994). 
d) Certain similarities between English and Persian ellipsis do not necessarily result in easier learning and fewer errors on the part of EFL learners. This is in line with the moderate version of contrastive analysis which holds that similarities between L1 and L2 are not necessarily facilitative; rather they are debilitative and make language learning more difficult and result in more errors (Ziahoseny, 2008).

e) Differences between the Persian and English ellipsis mainly result in difficulties in the use of ellipsis in English and more errors both in writing and speech.

\section{Conclusion and Discussion}

Based upon the findings of this study, it can be suggested that English teachers and instructors while teaching the grammatical tie of ellipsis to Iranian students they take into account the similarities and differences between the Persian and English system of ellipsis. They are also required to distinguish between facilitative and debilitative similarities because each may have a different effect upon the success of ellipsis learning.

It is also suggested that textbook developers take into account the results of the present study and incorporate more exercises and practices in those areas of ellipsis where Persian is different from English. They are also recommended to build in fewer exercises and practices in those areas where Persian and English system ellipsis are similar so that learners can notice the differences.

Test developers can also benefit from the findings of this study. The errors which Iranian EFL learners are predicted to commit in respect to English ellipsis could function as distracters in multiple choice grammar tests.

The present study signified the importance of cohesion in the interpretation of texts and demonstrated how we can help students improve their EFL reading by analyzing cohesive devices and using cohesive devices as signposts. It can be concluded that cohesion has an important role to play in $E F L$ reading. However, for a more systematic application of the theory to the teaching of EFL reading, more research is needed in order to identify the overall relationship between different cohesive devices in the native and target language of learners and their possible contribution to the ease or difficulty of language learning.

\section{REFERENCES}

Baker, M. (1992). In other words: A course book on Translation. London \& New York: Routledge.

Bloor, Th., \& Bloor, M. (1995). The Functiona Aanalysis of English: A Hallidyan Approach. London \& New York: Arnold.

Cook, V. J., \& M. Newson (1998). Chomsky's Universal Grammar: An Introduction. Oxford: Blackwell Publishers.

Farshidvard, K. (1969). Dastour-e-emrouz. Bongah Matbooati Safi Alishah, Tehran.

Halliday, M. A. K. (1985). An Introduction of Functional Grammar. London: Edward Arnold.

Halliday, M. A. K., \& Hasan, R. (1976). Cohesion in English. London: Longman.

Hasan, R. (1984). Coherence and Cohesion Harmony. Delaware: International Reading Association.

Kavousi N., S. (1997). "Ellipsis in Persian". Farhangestan, 3, 146-66.

Kavousi N., S. (1998). "Nominal Ellipsis in Persian”. Farhangestan, 4, 109-27.

Khayyampour, A. R. (2002). Persian Grammar. Tehran: Sotude Publication.

Keshavarz, M. A. (1994). Contrastive Analysis and Error Analysis. Tehran: Rahnama Publications.

Larson, M. L. (1984). Meaning-based translation: A guide to cross-language equivalence. Lanham: University Press of America.

Mashkour, M. (1994). Persian Grammar. Mashhad: Ferdowsi University Publication. 
McCarty, M. (2005). Discourse Analysis for Language Teachers. London: Cambridge University Press.

Miremadi, S. A. (1998). "Ellipsis in Persian: Principles and restrictions". Language and Literature Journal, $3,37-85$.

Palmer, C. J. (1999). "Coherence and Cohesion in the English Language Classroom: The use of lexical reiteration and pronominalisation". RELC Journal, 30 (2), 61-58.

Quirk, R. Greenbaum, S. Leech, G., \& Startvik, J. (1985). A comprehensive grammar of the English language. London: Longman.

Richards, J. C., \& Schmidt, R. (2002). Dictionary of language teaching and applied linguistics. ( ${ }^{\text {rd }}$ ed.). UK: Longman.

Vahidian, K. T. (1969). Common grammar. Tehran: Amirkabir Publisher.

Ziahosseiny, S. M. (2008). Contrastive analysis of Persian and English and error analysis. Tehran: Rahnama Publications. 